\title{
KAPCSOLATI STRATÉGIA ÉS ÉRTÉKTEREMTÉS AZ ÜZLETI PIACOKON
}

Az üzleti kapcsolatok iránt megélénküló figyelem az értékkoncepció elôtérbe kerülésével hozható összefüggésbe. A paradigmaváltás alapját a kapcsolatokból az eladók és a vevốk számára nyerhetố többletérték jelenti, amelynek realizálása azonban szervezeten belül is megköveteli a kapcsolati magatartás érvényesítését. Jelen cikk a kulcsfolyamatok mentén haladva mutat rá a belsố és a külsố kapcsolatmenedzsment összefüggéseire. Kiemeli az interakciós és kommunikációs folyamatok integrálásának értékteremtésben játszott szerepét, az ehhez szükséges szemléletbeli változásokat, valamint az ezt elôsegítő menedzsmenttechnikákat.

\section{Kulcsszavak: kapcsolati stratégia, kapcsolatmenedzsment, kapcsolati érték, hálózat}

A XXI. század marketingértelmezésének egyik meghatározó dimenziója a kapcsolati szemlélet. Az új marketingparadigma a kapcsolatok értékteremtố szerepének a felismerésén alapul. A tranzakciós megközelítés felváltása a korábbi szervezeti struktúrák lebontásának a talaján megy végbe, a szervezeti filozófia és a kapcsolati szereplók attitúdjének alapvetô megváltoztatását igényli.

\section{Kapcsolati nézópont a szervezeten belül és a külsố relációkban}

A kapcsolati koncepció lényege a folyamatközpontúság. A kapcsolati marketing stratégiája három kulcsfolyamatra épül: interakciós folyamat, tervezett, kommunikációs folyamat és értékfolyamat (Grönroos, 2004). A folyamatok menedzselése a tranzakciókhoz képest bonyolultabb és szélesebb körú kitekintést igényelő feladat. Ennek okai a következók:

- Kapcsolati szintek: a szervezeti kapcsolatok különböző szintekre bonthatók, melyeket a vállalatoknak párhuzamosan kell kezelniük. Ide sorolhatók a kétváltozós kapcsolatok (eladó-vevô relációk), a kapcsolati portfólió, a vevoók vevóivel vagy a szállítók beszállítóival fennálló közvetett kapcsolatok és a hálózat (Ritter et al., 2004).

- Kapcsolati feladatok: a menedzselési feladatok két nagy csoportra oszthatók (Ritter et al., 2004). A kapcsolaton átívelő (keresztkapcsolati) feladatokhoz sorolható az egyes relációk részcéljainak definiálása, a kapcsolatokban rejlő szinergiák kiaknázása, a pénzügyi erőforrások allokálása. A kapcsolatspecifikus feladatok az eladók-vevók közti kapcsolati folyamatokra vonatkoznak.

- Kapcsolati fázisok: egy vállalatnak egyidejúleg különböző fejlettségi szinten álló kapcsolatai lehetnek. A menedzselési feladatok között egymás mellett szerepelhet a potenciális partnerek beazonosítása, új kapcsolatok kialakítása, meglévók ápolása és magasabb szintre történô emelése, de akár a kapcsolat leépítése, illetve a megszúnés következtében beálló helyzet kezelése.

- Érintkezési pontok: a kapcsolati folyamatoknak mindig vannak olyan érintkezési pontjai, amelyek kritikus jelentőségúek a realizálható előnyök, illetve a kapcsolat jövője szempontjából. Ezek sikeres menedzselése a kapcsolat jellegétôl, fontosságától függő́n eltérô megoldások, technikák alkalmazását kívánja meg.

- Kapcsolati kihatások: az egyes tranzakciókat csak azoknak a kapcsolatoknak a tükrében lehet megérteni, amelyeknek a részét képezik, az egyes kapcsolatokat pedig csak annak a hálózatnak a kontextusában, amelyen belül múködnek (Ford, 2003).

- Kapcsolati jellemzók: a kapcsolati jellemzók idôról idôre változnak. Átértékelődik az egyes relációk fontossága és változnak a kapcsolaton belüli történések is. Az átalakulások a kapcsolatok gazdasági és társadalmi oldalát egyaránt érinthetik. 
A folyamatmenedzsment-döntéseknél a fenti szempontok mindegyikét szem előtt kell tartani. Egyaránt od kell figyelni a kapcsolati portfólióra, a kulcs eladó-vevó kapcsolatokra, az egyes interakciókon belüli történésekre és mindezek kölcsönhatásaira. Folyamatosan át kell látni és újraértékelni a függôségi viszonyokat, az egyes kapcsolatok közvetlen szerepét és hálózati kihatásait.

\section{Interakciós folyamatok a szervezetek között}

Az interakciós folyamatok a kapcsolati stratégia kiindulópontját jelentik, ezek mentén lehet kihasználni és fej-

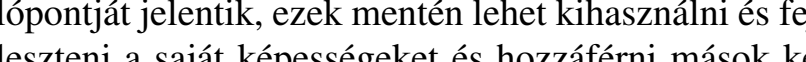

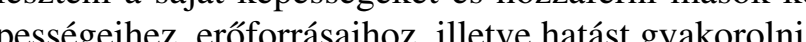
pességeihez, eróforrásaihoz, illetve hatást gyakorolni a tranzakciós és a kapcsolati megközelítés különbségé tranzakciós és a kapcsolati megkôzelítes külônbségé jôl szemlélteti az interakciós folyamatok különböz szintekre bontása. Az interakciós szintek a következố (Grönroos, 2004)

- Akciók: az akciók (például gyárlátogatás, kifizetés, reklamációküldés) a legkisebb komponensek, amelyek az interakciós folyamat bármely eleméhez kapcsolódhatnak, a fizikai termékektól vagy szolgáltatásoktól a társadalmi aspektusokon át a pénzügyekig. - Epizódok: az epizódokat (például tárgyalások, java szállítása, információcsere) az egymáshoz kölcsönösen kapcsolódó akciók alkotják.

Folyamatok: az egymáshoz kapcsolódó epizódokból épülnek fel a folyamatok (ajánlatok, projektek, kampányok), amelyek mindig egy adott időszakhoz köthető́k

- Kapcsolat: a kapcsolat számos folyamatból áll. Ezek közvetlenïl követhetik egymást, hosszabb-rövidebb idô is eltelhet közöttiik, de akár átfedésben is lehetnek egymással.

A tranzakciós megközelítés egy-egy epizódra szorítkozik. A vevő számára nyújtott megoldás az epizód tárgyát képezô termék vagy alapszolgáltatás. A kapcsolati stratégia a folyamatra irányul. A fogyasztás tí-

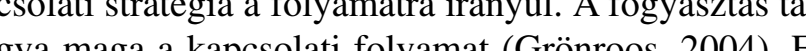

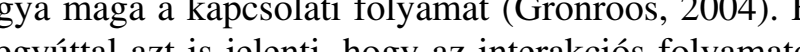
egyuttal azt is jelent, hogy az interakcios folyamatok menedzselése során minden elemet, torténést a kapcsohi. Az egyes komponjabol kell kialukituies erteket$n i$. Az egyes komponensek befolyásolhatják és helyettesíthetik is egymast. A menedzselési szempontokba b kell építeni ezeknek egymásra, a kapcsolatra, illetve hálózati pozícióra való kihatásait. Mivel a kapcsola szintek és az egyes relációs történések nem választhatók el egymástól, a döntéseknek ki kell terjedniük az erőforrások allokálására az egyes kapcsolatok és azok különbözó epizódjai között.

\section{Kapcsolatorientáció a szervezetben}

A kapcsolati bánásmód az üzleti partnerek irányában kapcsolatorientált magatartás szervezeten belüli érvényesítését feltételezi. Ehhez olyan keretrendszer kialakítására van szükség, amely strukturális és kultuális oldalról egyaránt a kapcsolati szemléletet pártfogolja és menedzsmentmegoldásaival ennek gyakorlat ervényesítését segíti elő. A kapcsolatok szervezeten belül is különböző szintekre bonthatók, ezért egyéni (vezetók és alkalmazottak), csoportszintú (funkciók és részlegek), valamint hálózati (keresztfunkcionális és interperszonális) dimenziókat egyaránt figyelembe kell venni. Egymás mellett kell megoldani keresztkapcsolati és kapcsolatspecifikus (például marketing és értékesítés) feladatokat Ki kell válasz mi es haćkonyan alka felo

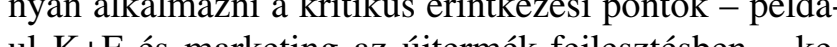
ul K+F es marketing az ujtemek-fejleszlésben - keA verika lis szelrvezetôb here A vertikatis szervezeti hierarchiát lebontva teret kel adni a keresztfunkciós csapatok alkotta megoldásnak. A szervezeti kultúrának osztônôznie kell a kooperácios, a bizalmi és a kölcsönös függő́ségi attitúd kialakítását (Kothandaraman - Wilson, 2000).

\section{Interakciós folyamatok a szervezeten belül}

Az interakciós folyamatok szervezeten belül is felbonthatók akcióra (telefonhívások, levelek), epizódra (tárgyalások, belső́ információcsere), folyamatokra (termékfejlesztési projektek) és kapcsoltra.

A tranzakciós szemlélet az eseti jellegú érintkezéseket - tárgyalások, telefonhívások, bizottságok - állítja középpontba. A szervezeten belül múkoödő funkciócsoportok jól definiált célok elérése érdekében, előre meghatározott elvárások mentén tevékenykednek. A hangsúly az eseti érintkezések gyakoriságán és ezen keresztül a minél intenzívebb információáramláson van. A tranzakciós gyakorlat elónyei a számszerúsíthetőség, a jó ellenőrizhetőség, a rendszeresség és kiszámíthatóság, az adott struktúrába való beilleszthetôség (Kahn,1996). Hátránya azonban, hogy fennmarad a rivalizálás az eróforrásokért folytatott versenyben. A „nem itt találták fel" szindróma és az eróltetett interakciók konzerválják a távolságtartó vagy akár ellenséges magatartást, blokkojúk az informácícsét Eat mes Ezt még fokozhatja a sze-

A kapcsolati szemlélet a kapcsolati normákfejlesztését (rugalmasság, a célok megosztása, szolidaritás, pozitív érdeklődés, összetartás és támogatás, tudatosság, bizalom) állítja a középpontba. Ezt a vezetés - feltéve, hogy felismerte a fontosságát - különbözó menedzs- menttechnikákkal segítheti elố. Ilyen megoldások például a célazonosságon alapuló osztott erớforrások, az emberek funkciók közti mozgatása. Mivel nem ese beszabályozott keretek között történő érintkezésekrố van szó, az eltérő szakmaisággal, érdekekkel, motivációkkal rendelkezó szereplốk között szükségszerúe konfliktusok keletkeznek. Ezek kezelése a vezetéstố pluszenergiát igényel. Miután a cél nem az eseti érintkezések növelése, hanem a kapcsolati normák fejlesztése, az eredmények is csak hosszabb távon várhatók.

\section{Kommunikációs folyamatok a szervezete}

\section{közti kapcsolatokban}

A kommunikációs folyamat - forrásai és formái alapján - szintén több komponensból épül fel (Grönroo 2004). Az eladók tervezett kommunikációs üzeneteine középpontjában a vevő problémájának a megoldása ál. Az eladók-vevốk közti kommunikáció interaktív jellegú: Az eladó tájékoztatja a vevốt a megoldásról, a vevó pedig információt nyújt problémájának természetéról a felhasználás, alkalmazás várható módjáról. A tervezett kommunikáció részét alkotó termék- és szolgáltatásüzenetek kiegészíthetik, illetve bizonyos esetekben akár helyettesíthetik is egymást. A kapcsolatokban jelentôs szerepet játszhatnak a nem tervezett üzenetek, jelentôs szzerepet játszhatnak a nem tervezett üzenetek, amelyek a kommunikációs és interakciós folyamatr illetve a kettó viszonyára egyaránt vonatkozhatnak. Id sorolhatók a referenciak is. A kepcsolat megitélésére a kommunikació hianya (az el nem küldôtt vagy megké sett üzenetek) is jelentôs kihatással lehet.

A kommunikációs elemek és formák befolyásolhatják és helyettesithetik egymást, ezért itt is fontos szempon kapcsolati kihatásuk alapján történő összehangolásuk.

Kommunikációs folyamatok a szervezeten belï

A kapcsolati megközelítés tudásmegosztásra és -integrációra épít. Az információk megosztására azonban nehezen állnak át a tudásfelhalmozáshoz szokott menedzserek, akik nogyon ḱnyelmetlezïl ćzik maguk üil érzik magukat, ha sikerük mások telest leváns információka a cegen belúl nem szivivesen osztj meg egymással, aligha váháó el, hogy ezt tegyék kül üzleti partnereikkel. Nem véletlen, hogy a stratégiaközpontú szervezetek a tudásmegosztást alapvetó stratég képességként jelölik meg (Kaplan - Norton, 2002).

$\mathrm{Az}$ információmegosztás alapfeltétele a hatékony kommunikáció. Ez viszont jórészt azon múlik, hogy milyen mértékben sikerül áthidalni a szakmakulturák köz távolságot, ami megmutatkozik az eltérő látásmódban, értékekben, problémaértelmezésben, megoldási ruti- nokban. Az eltéró szakmai nyelvezet is - különösen a múszakiak és a marketingesek esetében - jelentốs gátja A az információk befogadásának és feldolgozásának. A tranzakciós megközelítés a formális hierarchia ssatornáin keresztül történő kommunikációt részesíti előnyben (tervezett megbeszélések, standardizált dokumentumáramlás). A kapcsolati szemlélet az informális kommunikációt támogatja. Az így létrejövő informális hálók ösztönzően hatnak a kapcsolati normák fejlődésére. Ha a szereplốk kölcsönösen támogatják a kapcsolatot, akkor - egymás tudását és képességeit felhasználva - a közös célok elérése érdekében fognak tevékenykedni.

\section{Értékfolyamatok a szervezetek közti}

\section{kapcsolatokban}

z értékfolyamatok a kapcsolati stratégia kimeneteént értelmezhetók. Mivel a folyamatok menedzselése osszetettebb feladat, mint a tranzakcióké, ezért pozitív hozadékának meg kell jelennie az értékteremtésben is (Grönroos, 2004). A többletérték két oldalról ragadható meg: A termékértéket pozitív vagy negatív irányban befolyásoló szolgáltatásérték és az epizódokon túlmutató kapcsolati érték.

A kapcsolati marketingstratégia kritikus elemét a kapcsolati érték feltárása és menedzselése jelenti. Enek okai a következókben foglalhatók össze:

A kapcsolati értéknek gazdasági és társadalmi összetevói is vannak;

- Az eszlelés az egyének és a csoportok szintjén is megtörténik;

A kapcsolat értékelése mindig szubjektív és változó, az érintettek percepciójának függvényeként alakul;

A kapcsolati értéket nem könnyú demonstrálni

- Az epizód- és a kapcsolati elemek, a gazdasági és a társadalmi dimenziók, valamint ezek értékkomponensei kölcsönösen befolyásolják egymást.

Az értékészlelés során az epizód és kapcsolati érték nem választható el egymástól (Grönroos, 2004) A kapcsolati érték az egyes epizódok megítélése - termék szolgálttúcéték és teljesítés - alapján formálódik. Az összefïgés forditva is igaz: A kapesoltti éték - olyan tényezók mentén, mint például a bizalom, bizton - ógérzet - növelheti az epizód értéket, sốt a hangśly aḱr ́t

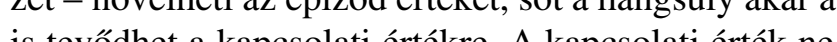
is teviv met a kapcsolati ertékre. A kapcsolati erték neepir eizodok létrejôtet, hacsak nem szolnak olyan érvek kapcsolat mellett, mint például a földrajzi közelség Az uz erơfrásokra való ráutaltság.

az üzleti kapcsolatok értéke gazdasági (hasznossái) és társadalmi (motivációs) osszetevókból épül fel. 
Míg az elózőek a gazdasági értelemben vett bevétele és kiadások kifejeződései, utóbbiak a kapcsolattal öszszefüggó társadalmi interakciókat írják le (Mandják, 2004). Ford (2003) szerepkötelékeknek nevezi a kapcsolatok társadalmi oldalát, amely olyan elemekbố áll, mint az érzelmek, az értékek, az elkötelezettség, bizalom. Ritter et al. (2004) a ,,soft értékteremtő funkció" kifejezést használják, kiemelve, hogy a cégek nem egy esetben a korábbi sikeres együttmúködés, a szociấlis támogatás, vagy pusztán a jó érzés" miatt tartanak fenn egy-egy kapcsolatot.

\section{A vevoértek komponense}

(Grönroos, 2004. 104. alapján)

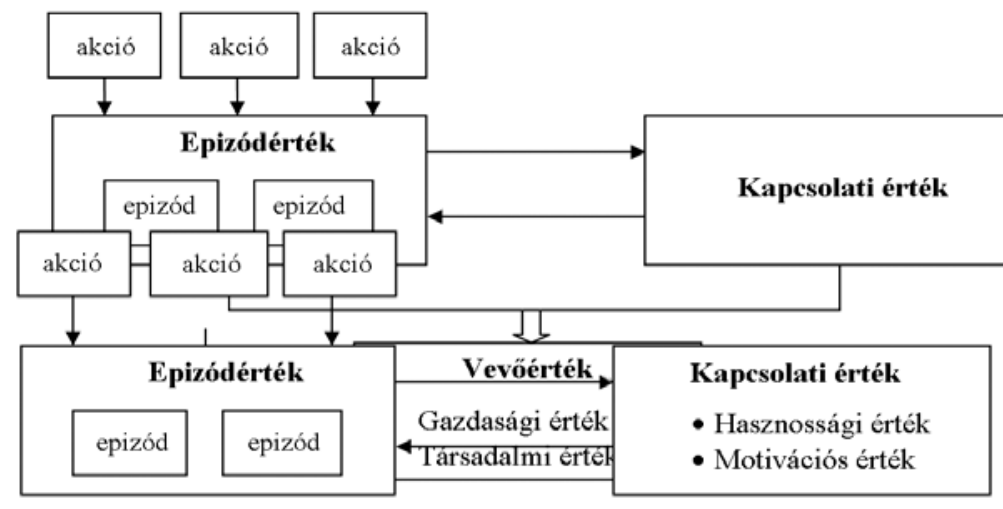

A kapcsolati döntések fontos szempontja a hálózati hatások figyelembevétele. A hálózati környezetre jellemző:

- Közvetett partnerkapcsolatok is létrejöhetnek;

A kozvetlen partnerek indirekt értékteremtő szerepet is betölthetnek.

A közvetett partnerekhez a vállalat egy harmadik fél évén kötődik, amellyel mindketten kapcsolatban állnak (Holmen - Pedersen, 2003). Ók biztosítják az összeköttetést a kétváltozós kapcsolatok és a hálózatok között.

1. ábra A közvetett funkciók értékalkotó szerepe kulcskapcsolaton kívüli relációkkal való összefüggésben értelmezhetô. Közvetett funkciók például azok, amelyek a további partnerekkel való kapcsolat kialakításának (hozzáférési funkció), a kritikus fontosságú információkhoz való hozzájutásnak (felderítő funkció) vagy az új piacokhoz való hozzáférésnek (piaci funkció) a lehetôségét teremlik meg (Lindgreen - Wynstra 2005). Ezek (ö) Ezek még fory kis teljesítményú közek be, hogy még egy kis teljesinćn kónzvetlen érékte-

A hálózati lehetóségek kibapsolotot.

A hálózati lehetőségek kihasználásához hálózati képességek elsajátítására van szükség. A vállalatnak tudnia kell „olvasni” a hálózatból, ismernie saját pozícióját és annak változásait, megérteni a hálózat dinamikáját és azt, hogy a partnerek hogyan gondol-

Az üzleti kapcsolatok értékét mindazok észlelik, akik a kapcsolatban részt vesznek, vagy akik a kapcsolat által érintettek, ezért egyéni és csoportos észle let egyaránt létrejön (Mandják, 2004). A percepcióba jelentős eltérések lehetnek, akár az egyes epizódok, akár a kapcsolat értékére vonatkozóan. Ezért nagy hangsúlyt kell fektetni a partner döntési folyamatainak átlátására, az elónyök és a döntéshozók összekapcsolasára (Anderson et al., 2006). Az eladóknak kapcsola sara (Anísuk kialakításakor a vevók belsö́ étékteromi

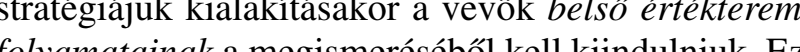
biztositték annak, hogy az értékajánlatok ne a vélelmezett érteken, hanem a megismert vevô értékpreferenciákon alapuljanak (Anderson et al., 2006).

A kapcsolat észlelt értéke idôról idôre változik. A partneri viszony annak függvényében alakul, hogy sikerül-e az elvárásokat összehangolni, az eladói és vevới csoportészlelet megfelelését biztosítani (Mandják, 2004; Piercy - Lane, 2006). Ha ez folyamatosan megtörténik, akkor az így létrejövő elkötelezettség és bizalom többletêrtéket hoz létre mindkét fél számár kodnak saját hálózati kontextusukban. Ahogy az egyes i döntések megalapozása érdekében tájékozottnak kell

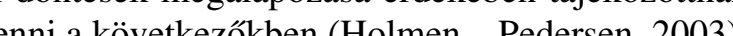

A közvetlen partnerek hogy látják el a közvetítói funkcióikat, mennyiben segítik a hálózati hozzáférést? Milyen szintû́ a hálózati rálátás a direkt partnerek közvetítói funkcióin keresztül?

- Melyek a stratégiai elképzelések a hálózat változása esetén, és melyek ennek várható kihatásai?

A hálózati hatás tovább növeli a kapcsolati folyamaok menedzselésének összetettségét. Egy eladó-vevô kapcsolat több közvetlen és közvetett funkciót elégíthet ki egyszerre. Az egyes funkciók jelentôsége eltérhet egymástól különböző partnerek esetében, de ugyanazon partnernel is, az egyes kapcsolati szakaszokban.

A fentiek jol mutatjak, hogy hálózati kornyezetben a stratégiaalkotás interaktív, fejlódó és alakitható (Ford, 2003). A szereplốk a saját érdekeik szerint próbáljakk kezelni a kapcsolatokat, miközben céljaikat és változnak, amit be kell építeni a stratégiába. A kapcsola- elvárásaikat a többi relációjuk s a hálózati hatások is befolyásolják. Minden egyes kapcsolati döntés a változások olyan sorát vonhatja maga után, amelyeket csak összefüggéseikben lehet szemlélni.

\section{A kapcsolati folyamatok kölcsönhatásai}

Az interakciós és a kommunikációs folyamatok egymással kölcsönhatásban vezetnek el az értékfolyamathoz, ezért a belső összhangjuk mellett ezek integrálását is szem elôtt kell tartani (Grönroos, 2004). A diszh mónia negatív, nem tervezettïzeneteketeredményezhmind a partner szervezetén belül, mind a hálózatbon.

Az érték az interakciós folyamatok során születik. A marketingkommunikációs folyamatoknak ezt támogatniuk kell az interakciós folyamat megkezdése elót és annak során (Grönroos, 2004). Másik oldalról nézve: A hatékony kommunikáció nélkülözhetetlen feltétele interakciós folyamatból nyerhetó érték meg-és felism résének. Az interakciós folyamatok létrejötte sokszor azért hiúsul meg, mert nem sikerül demonstrálni a várható értéket. A pozitív kommunikációs üzenetek persze csak akkor segítik a kapcsolat fejlődését, ha az interakciós folyamatok során az ígéretek meg is valósulnak.

Az üzleti piacok változásai nyomán az egymás képességeitôl, erőforrásaitól, valamint hálózati hozzáférésétôl való kölcsönös függés erősödik. A kapcsolatok sikeres kezeléséhez mind több funkcionális területró kell szereplóket bevonni, miközben a kommunikációs eszköztár bővülésével az interakciók koordinálása megnehezül (Ford, 2003). A holisztikus szemlélet, kapcsolatmenedzselési képesség elengedhetetlen feltételei a kapcsolati hatások átlátásának és megértésének. Ugyancsak ezek segíthetnek megtalálni a célravezetó menedzselési megoldásokat a partner megismerésétó kezdve a bizalomépítésen át a távolság, a konfliktusok, vagy éppen a függőség kezeléséig. A szervezetek közti hálózati és kapcsolati szituációk kooperativv, kompetitîv és konfliktuselemeket egyaránt tartalmaznak (Ritter al., 2004). A kapcsolatok jelentőségének, gazdasági és társadalmi szerepének folyamatos átértékelő́ćse korültekintố mérleoele feladatok prioritásainak meghatározásánál is.

\section{Értékteremtő folyamatok a szervezetben}

A tranzakciós szemlélet az értékteremtést az egyes funkcionális inputokhoz köti. Külsố relációban ez úgy jelenik meg, hogy a szervezeten belüli értékteremtés két - hagyomanyos szerepet betöltó - funkcionál területbe, a marketingbe és beszerzésbe integrálódik. Ezen keresztül történik a két vállalat közti kommuni- káció és bonyolódik le a csereügylet (Kothandaraman Wilson, 2000).

A kapcsolati paradigma a funkciókon átíveló $\mathrm{fel}$ adatokból, tevékenységekból indul ki, amelyek az értékfolyamatban összekapcsolódnak. Kifelé ez úgy jelenik meg, hogy a különbözó értékteremtố funkcióihoz köthetô információk, képességek és erőforrások szabadon aramolnak a kapcsolati célok megvalósítása érdekében (Kothandaraman - Wilson, 2000).

A kapcsolati értéknek szervezeten belül is vannak azdasági és társadalmi összetevőii. Az értékteremtéshez szïkséses tud́s és képességek összekapcsoĺsa az együttmúködő magatartás révén az üzleti êcényeség ku A tár a

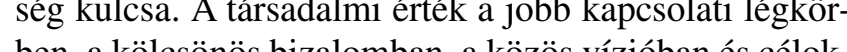
ben, a kolcsós bizalo Ezan, a kozos vírióbás celokban mutatkozik meg. Ez az üzleti partnerek irányában is a párbeszédre, az interaktív együttgondolkodásra, a közös tudásbázis gyarapítására motiválja az egyéneket.

\section{Felhasznált irodalom}

Anderson, J.C. - Narus, J.A. - Rossum, W. (2006): Vevóertek-ajânlatok üzleti piacokon. Harvard Business manager. Nov. 65. o.

Ford, D. (2003): Business marketing. Budapest, KJKKERSZOV Kiadványo

Grönroos C. (2004): The Relationship Marketing Process: Communication, Interaction, Dialogue, Value. Journal of Business \& Industrial Marketing. Vol. 19, No. 2, 99-11. o. Holmen E. - Pedersen A.N. (2003): Strategizing through Analyzing and Influencing the Network Horizon. Industrial Marketing Management. Vol. 32. 409-418. o. Kahn, K.B. (1996): Interdepartmental Integration: ADefinition with Implications for Product Development Performance, Journal of Product Innovation Management, Vol. 13, No 2, 137-151. o.

Kaplan, R.S. - Norton, D.P. (2002): A stratégiaközpontú szervezet. Panem Kiadó, Budapest

Kothandaraman, P. - Wilson, D.T. (2000): Implementing Relationship Strategy. Industrial marketing management. Vol. 29. 339-349. o.

Lindgreen, A. - Wynstra, F. (2005): Value in Business Markets. What do we Know? Where are we going? Industrial Marketing Management, Vol. 34, 732-748. o.

Mandják T. (2004): Az üzleti kapcsolatok marketingertelmezése. In: Marketingelmélet a gyakorlatban. KJKKERSZOV Kiadványok, (szerk.: Berács József - Lehota József - Piskóti István - Rekettye Gábor)

Piercy $N$. - Lane N. (2006): The Underlying Vulnerabilities in Key Account Management Strategies. European Management Journal, Vol. 24, No. 2-3, 151-162. o.

Ritter, T. - Wilkinson, I.F. - Johnston, W.J. (2004): Manging in Complex Business Networks. Industrial Marketing Management Vol. 33, 175-183. o. 